\title{
Analyse pragmatique de titres de presse écrite britannique : médiation entre pouvoir politique et lectorat
}

Jean-Louis Legalery

\section{(2) OpenEdition}

\section{Journals}

Édition électronique

URL : http://journals.openedition.org/asp/4479

DOI : $10.4000 /$ asp. 4479

ISBN : 978-2-8218-0388-6

ISSN : 2108-6354

\section{Éditeur}

Groupe d'étude et de recherche en anglais de spécialité

Édition imprimée

Date de publication : 1 décembre 2002

Pagination : 61-72

ISSN : 1246-8185

\section{Référence électronique}

Jean-Louis Legalery, "Analyse pragmatique de titres de presse écrite britannique : médiation entre pouvoir politique et lectorat », ASp [En ligne], 35-36 | 2002, mis en ligne le 04 août 2014, consulté le 21 avril 2019. URL : http://journals.openedition.org/asp/4479; DOI : 10.4000/asp.4479

Ce document a été généré automatiquement le 21 avril 2019.

Tous droits réservés 


\section{Analyse pragmatique de titres de presse écrite britannique : médiation entre pouvoir politique et lectorat}

Jean-Louis Legalery

\section{NOTE DE L'ÉDITEUR}

L'auteur de cette contribution n'a pas autorisé sa publication en ligne.

\section{RÉSUMÉS}

L'analyse pragmatique et sémantique de titres de une de quotidiens et hebdomadaires britanniques, depuis la victoire travailliste aux élections législatives de mai 1997 et la nomination de Tony Blair à la tête du nouveau gouvernement, conduit à considérer les rapports qui s'instaurent entre les signes linguistiques et leurs utilisateurs. Les titres de première page classent et hiérarchisent l'information. Ils sont au carrefour de deux missions contradictoires : produire un signal graphique, censé être aisément et rapidement identifiable, et fournir aux lecteurs un message significatif. La signification peut tout d'abord être liée à la taille des titres et à leur position sur la première page. Elle peut aussi être déterminée par les associations lexicales et structurelles, plus particulièrement considérées selon l'analyse fonctionnelle de Halliday. Enfin, les choix sémantiques renforcent la spécificité d'un titre. La médiation que crée le langage se fonde sur sa conception politique et sociale. À la lumière des travaux de Gumperz, Lakoff et 
Bourdieu, la médiation des titres de une, par le biais d'une analyse pragmatique, peut également caractériser le langage comme vecteur de pouvoir.

The pragmatic and semantic analysis of British newspapers' front page headlines, since Labour's landslide victory in the general elections of May1997 and the appointment of Tony Blair as the new Prime Minister, leads us to consider the relationships between linguistic signs and their users. Front page headlines classify the news and organize it into a hierarchy. Headlines are at the crossroads of two contradictory assignments: producing a graphic signal, which is supposed to be easily and quickly identifiable, and providing readers with a meaningful message. The meaning of headlines can first of all be based upon their size and the space they occupy. It also touches on lexical and structural associations, more particularly considered under the angle of Halliday's functional analysis. Finally, semantic choices reinforce the specificity of a headline and, with the help of Gumperz, Lakoff and Bourdieu's works, language can also be defined as a vector of power through the mediation of frontpage headlines.

\section{INDEX}

Keywords : functional analysis, mediation, power, pragmatics, semantics, front page headline Mots-clés : analyse fonctionnelle, médiation, pouvoir, pragmatique, sémantique, titre de une

\section{AUTEUR}

\section{JEAN-LOUIS LEGALERY}

Jean-Louis Legalery est professeur certifié d'anglais à l'IUT de Besançon, Université de FrancheComté. Il a été successivement rédacteur en chef du Polyglotte, supplément des Langues Modernes, de 1991 à 1995, et des Cahiers de l'APLIUT, de 1997 à 2000. Il a passé le DEA de Langue anglaise des spécialités scientifiques et techniques en 1999, auprès de l'Université de Bordeaux 2. Il travaille actuellement à la préparation d'une thèse portant sur les titres de presse anglophone. Ses centres d'intérêt sont la titrologie, la pragmatique, la linguistique systémique fonctionnelle et les actes de langage. Jean-Louis.Legalery@wanadoo.fr 